CAMBIOS ESTACIONALES DE LA ABUNDANCIA

DEL CAMARON CAFE (Penaeus aztecus)

DE LA ZONA NOROCCIDENTAL DEL GOLFO DE MEXICO

Y SU RELACION CON PARAMETROS AMBIENTALES

\title{
SEASONAL CHANGES OF BROWN SHRIMP (Penaeus aztecus) ABUNDANCE IN THE NORTHWESTERN GULF OF MEXICO RELATED TO ENVIRONMENTAL FACTORS
}

\author{
Rafael Solana-Sansores* \\ Francisco Arreguín-Sánchez** \\ Centro de Investigación y de Estudios Avanzados \\ del Instituto Politécnico Nacional \\ Unidad Mérida \\ Apartado postal 73-Cordemex \\ 97310 Mérida, Yucatán, México
}

Recibido en marzo de 1991; aceptado en marzo de 1993

\section{RESUMEN}

Se analizó la relación entre los cambios estacionales de abundancia de la población de camarón café (Penaeus aztecus) que se explota en la zona noroccidental del Golfo de México y algunos parámetros ambientales: precipitación pluvial y esfuerzo pesquero. Utilizando la información de abundancia por clase de edad mensual (dada por la captura por unidad de esfuerzo) para el periodo de 1974 a 1982, se aplicó el análisis de componentes principales (ACP), del cual se obtuvo un índice asociado con la fuerza de reclutamiento (FR) y otro que representa la densidad de adultos (DA) (Solana-Sansores et al., 1989), el cual es inversamente proporcional al logaritmo de la abundancia de los mismos. Estos indicadores fucron analizados por medio del método multivariado de correlación canónica junto con los registros de precipitación y el esfuerzo de pesca. La primera correlación canónica $\left(R_{c}^{2}\right)$ fue altamente significativa $(\mathrm{P}<0.01)$ e involucra en los coeficientes más grandes al esfuerzo pesquero, dentro del grupo de variables ambientales, y a la fuerza del reclutamiento, dentro del grupo de índices poblacionales. Los resultados muestran cómo los factores ambientales contribuyen a explicar las fluctuaciones observadas en los patrones de comportamiento de la población analizada, lo cual sugiere la conveniencia de considerar dichos factores (precipitación pluvial y esfuerzo pesquero) en modelos predictivos para la pesquería.

\section{ABSTRACT}

An analysis was made of the seasonal changes of abundance of the brown shrimp (Penaeus aztecus) population in the northwestern Gulf of Mexico, related to environmental parameters such as rainfall and fishing effort. Using monthly age-class abundance data (given as catch per unit effort) for the period 1974 to 1982, a principal components analysis was applied and two population indexes were obtained: recruitment strength (as a monthly class strength) and adult density (Solana-Sansores ef al., 1989), which is inversely proportional to the log of their actual abundance. Both indexes and the records of environmental parameters were analysed using the

* Dirección actual: Facultad de Ciencias, Universidad Autónoma de Baja California, Apartado postal 1880, Ensenada, Baja California, 22800, México.

**Dirección actual: Programa EPOMEX, Universidad Autónoma de Campeche, Apartado postal 520, Campeche, 24030, Cam., México. Fax 91(981)65954. 
multivariate method of canonical correlation. The first canonical correlation was highly significant $(P<0.01)$ and includes mainly fishing effort and the recruitment strength index. The second one showed a high correlation between rainfall and the adult index. The results show how some environmental factors help to explain the fluctuations observed in the general behaviour pattern of the population. This suggests the convenience of incorporating these factors (rainfall and fishing effort) in fisheries models.

\section{INTRODUCCION}

Las poblaciones naturales tienen una vinculación estrecha con el medio ambiente y a lo largo de su evolución se han adaptado a éste, con cierta capacidad de respuesta a los cambios que se presentan, sea que correspondan a perturbaciones puntuales de corta o gran magnitud, o a variaciones ambientales que ocurren regularmente a lo largo del tiempo.

En cuanto a poblaciones de camarones peneidos, hay estudios sobre la influencia de diversos factores ambientales, como la precipitación pluvial y las descargas de ríos, sobre diferentes aspectos de la dinámica de la población. Se ha informado sobre migración de juveniles (García, 1984; Silas et al., 1984; Walker, 1984), reclutamiento (Staples et al., 1984; Unar y Naamin, 1984; Logan, 1985; García, 1984), abundancia de la población, supervivencia de las generaciones a lo largo del ciclo de vida y rendimientos obtenidos de la explotación pesquera.

La temperatura es otro de los factores importantes en la regulación de las poblaciones de camarones, ya que influye fundamentalmente en el crecimiento y los movimientos (Rothschild y Brunnenmeister, 1984).

Por otra parte, algunas actividades humanas, como el uso de tierras para propósitos agricolas, acuaculturales, etc., pueden afectar la dinámica poblacional de recursos como el camarón, ya sea por los efectos de contaminantes químicos y térmicos que producen un impacto considerable en la supervivencia, mortalidad y reclutamiento de esta especie o bien por sobrexplotación de ella, ante la perspectiva de obtener ingresos, fundamentalmente a través de la generación de divisas. En estos casos, la importancia de conocer con detalle la dinámica de las poblaciones asociadas a procesos de reclutamiento es de suma importancia, por la posibilidad de obtener larvas para engorda y el impacto que esto puede tener sobre las poblaciones natu-

\section{INTRODUCTION}

Natural populations are closely related to their environment. Throughout their evolution they have adapted to it, showing an ability to respond to changes that occur, be they punctual perturbations of a small or large magnitude or environmental variations that occur with certain regularity.

Regarding penaeid shrimp propulations, studies have shown the strong influence of several environmental factors, such as rainfall and river discharges, on different aspects of population dynamics, including juvenile migration (Garcia, 1984; Silas et al,, 1984; Walker, 1984), recruitment (Staples et al., 1984; Unar and Naamin, 1984; Logan, 1985; García, 1984), population abundance, survival of generations throughout their life cycle and yields obtained through fishery exploitation.

Temperature is another important factor regulating shrimp populations, since it basically influences growth and movement (Rothschild and Brunnenmeister, 1984).

On the other hand, certain human activities (e.g. the use of land for agriculture, aquaculture, etc.) may affect the population dynamics of resources such as the shrimp, either through the thermal and chemical pollutants used that have a significant effect on survival, mortality and recruitment of this species, or through its overexploitation for financial rcasons. In these cases, it is of prime importance to know in detail the dynamics of populations associated to recruitment processes because of the possibility of obtaining larvae for culture purposes and the impact that this may have on natural populations (Penn, 1984; Rothschild and Brunnenmeister, 1984; Van Zelenge, 1984; Silas et al., 1984; 
rales (Penn, 1984; Rothschild y Brunnenmeister, 1984; Van Zelenge,1984; Silas et al., 1984; Castro-Meléndez et al. 1986; Longhurst y Pauly, 1987).

Otros factores importantes como agentes de regulación y cambio en la dinámica poblacional de camarones peneidos son la velocidad y dirección de las corrientes, el tipo de alimento, la profundidad y tipo de substrato en que se distribuyen las especies, las fases lunares y, de manera particular, cómo influyen estos aspectos sobre la capturabilidad (Staples, 1985; Villegas y Dragovich, 1984; Cushing, 1984; Penn, 1984; Walker, 1984; Rothschild y Brunnenmeister, 1984; Longhurst y Pauly, 1987).

Con base en lo anterior, el objetivo del presente trabajo es analizar de manera integral algunas de las relaciones existentes entre las fluctuaciones de la abundancia de población del camarón café $(P$. aztecus) y la precipitación pluvial e intensidad de pesca.

\section{MATERIALES Y METODOS}

La información utilizada en este estudio proviene de los resultados obtenidos por Solana-Sansores et al. (1989), al aplicar la técnica de análisis de componentes principales (ACP) a la información sobre estructura por edades, tomando como variables la abundancia de las diferentes clases de edad mensual para el periodo de 1974 a 1982 . Esta información fue generada por investigadores del Instituto Nacional de Pesca con residencia en el Puerto de Tampico, Tamaulipas (México) e incluida en el informe de Castro-Meléndez et al. (1986). Partiendo de ese análisis, se observó que la contribución de las edades correspondientes a adultos explica la mayor parte de la variabilidad contenida en el primer componente y ocurre lo mismo con el segundo componente, el cual es explicado a través de la contribución de las edades involucradas (mes a mes) en el reclutamiento. De acuerdo con esto, se utilizaron los valores ponderales de cada componente para obtener los índices poblacionales que representan, dentro de cada componente, la fuente principal de variaciones según la siguiente relación:
Castro-Meléndez et al., 1986; Longhurst and Pauly, 1987).

Other important factors that influence penaeid shrimp population dynamics are speed and direction of currents, type of food, depth and type of substrate where species are found, lunar phases and, in particular, how these aspects influence catchability (Staples, 1985; Villegas and Dragovich, 1984; Cushing, 1984; Penn, 1984; Walker, 1984; Rothschild and Brunnenmeister, 1984; Longhurst and Pauly, 1987).

Thus, the aim of the present study is to analyse the relationship between the fluctuations in the abundance of the brown shrimp ( $P$. aztecus) population in the northwestern Gulf of Mexico, and rainfall and fishing effort.

\section{MATERIALS AND METHODS}

The information used in this study was taken from Solana-Sansores et al. (1989), applying principal components analysis (PCA) to the data on age structure, having as variables the abundances of different monthly age classes for the period 1974 to 1982. This information was obtained at the Instituto Nacional de la Pesca in Tampico, Tamaulipas (Mexico) and reported in Castro-Meléndez et al. (1986). From this analysis, it was observed that the contribution of the ages corresponding to adults explains most of the variability contained in the first component and the same occurs in the second component, which is explained by the contribution of the ages involved (month to month) in recruitment. Thus, the weighted values for each component were used to obtain the population indices which represent, in each component, the main source of variation, according to the following relation:

$$
I P_{1}=\sum_{\epsilon=1}^{n} w_{\epsilon}\left[\frac{U_{\epsilon, 1}-\bar{U}_{\epsilon}}{\sigma_{\epsilon}}\right]
$$


donde IPt es índice de población por mes, $r, \epsilon$, índice de edad; $W_{4}$, coeficientes de ponderación para las edades $\epsilon$ del componente principal; $U_{\varepsilon}$, abundancia por edad $\epsilon$, en el mes, $t, \bar{U}_{\mathrm{f}}$, valor medio de la abundancia de la eda e (expresada como captura por unidad de esfuerzo); $\sigma_{\epsilon}$, desviación estándar de $\theta_{\epsilon, t}$.

Si ' $I P_{t}$ es tomado del primer componente, se :obtendrá un índice de densidad de adultos $\left(\mathrm{DA}_{t}\right)$, el cual, de acuerdo con el $A C P$, es inversamente proporcional al logaritmo de la abundancia real En cambio, si $I P_{l}$ es tomado del segundo componente, el índice obtenido será directamente proporcional a la magnitud del reclutamiento parcial por mes, $t$ (o fuerza del reclutamiento, $\mathrm{FR}_{\mathrm{t}}$ ). Para mayor detalle, consúltese el apéndice.

Respecto a los parámetros ambientales, los valores de precipitación pluvial fueron obtenidos de los registros mensuales del Servicio MeteorológicoNacional, para el estado de Tamaulipas (Fig. 1) sobre el mismo periodo de tiempo que la información de abundancias poblacionales. El esfuerzo pesquero, referido como número de viajes mensuales, se obtuvo de Castro-Meléndez (1982).

Los supuestos principales asociados a este análisis son:

1) Dentro de cada índice poblacional, la capturabilidad es similar para las edades involucradas.

2) La explotación no es dirigida a tamaños específicos.

3) El esfuerzo pesquero se distribuye de manera homogénea en los campos de pesca y todas las embarcaciones de la flota tienen idéntica accesibilidad.

4) La curva de reclutamiento es de tipo de "filo de cuchillo" (jacknife).

Se examinó toda la información por medio del método multivariado de correlación canónica, CC (Morrison, 1976), para analizar y comprender las relaciones existentes entre variables poblacionales, parámetros ambientales e intensidad de pesca.

El método de CC se basa en la obtención de funciones lineales ortogonales para loṣ dos grupos de variables por analizar, particionando la matriz de varianza-covarianza (o correlación) y estimando los coeficientes de las where $I P_{t}$ is the population index for month $t$; the age index; $W_{i}$ the weighting coefficients for ages $E$ of the principal component; $U_{\epsilon}$ the abundance by age $\epsilon$ in month $t$; $U_{\epsilon}$ the thean value of the abundance of age $\epsilon$ (expressed as catch per unit effort); $\sigma_{e}$ the standard deviation of $U_{c} t$

If $I P_{t}$ is taken frow the first component; an index of adult density (DAt) will be obtained which, aceording to PCA, is mversely proportional to the logaritim of the actual abundance. In contrast, if $I P_{t}$ is taken from the second component, the index obtained will be directly proportional to the magnitude of partial recruitment for month $t$ (or recruitment strength, $\mathrm{FR}_{t}$ ). For details, see appendix?

The rainfall values for the same period covered by the population abundance data were obtained from the monthly records of the Senvicio Meteorológico Nacional, for the state of Tamaulipas (Fig. 1). Fishing effort, i.e. number of monthly voyages, was obtained fróm Castro-Meléndez (1982). are:

The main assumptions in this analysis

1) For each population index, catchability is similar for the ages involved.

2) Exploitation is not aimed at specific sizes.

3) Fishing effort is homogeneously distributed in the fishing areas and all vessels of the fleet have identical accessibility.

4) The recruitment curve is of the "jacknife" type.

In order to analyse the relationships between population variables, environmental parameters and fishing effort, the multivariate method of canonical correlation (CC) was used (Morrison, 1976).

The CC method is based on obtaining orthogonal linear functions for the two groups of variables to be analysed, partitioning the variance-covariance (or correlation) matrix and estimating the coefficients of the functions 


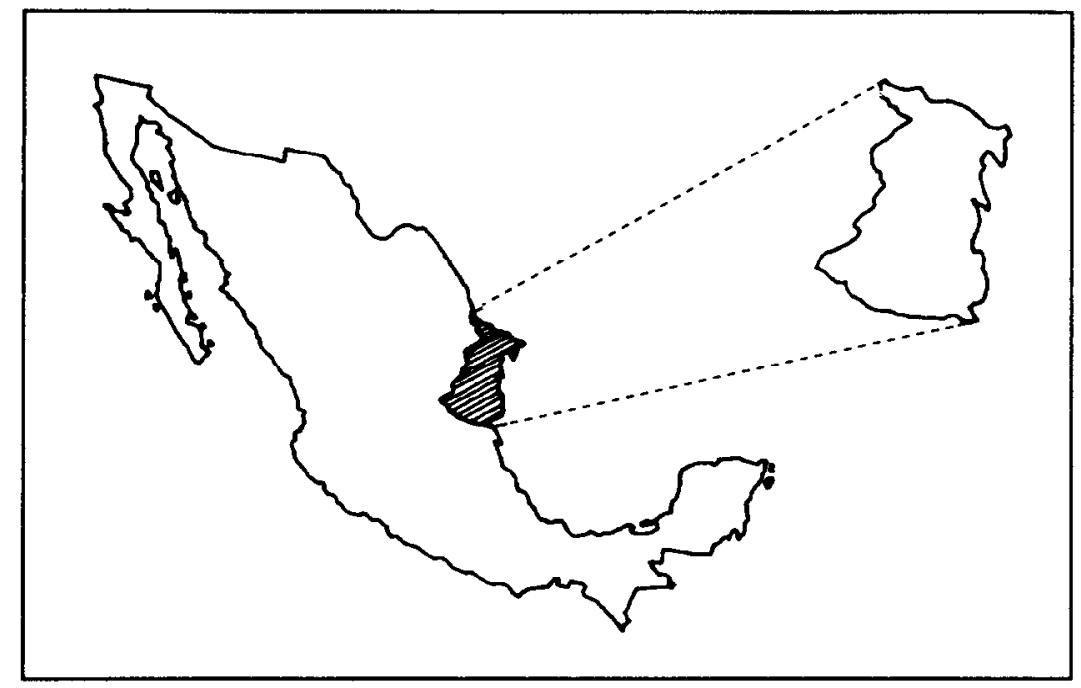

Figura 1. Estado de Tamaulipas (México).

Figure 1. State of Tamaulipas (Mexico).

funciones que maximicen el coeficiente de determinación de dichas funciones lineales $\left(R_{?}^{?}\right)$, denominado coeficiente de correlación canónica (Lee, 1971; Cooley y Lohnes, 1971; Morrison, 1976).

Los supuestos del método de $\mathrm{CC}$ sobre aleatoriedad de muestras $e$ independencia lineal entre las variables y dentro de cada grupo son, en principio, cubiertos con los supuestos señalados anteriormente, mientras que el supuesto de normalidad solamente es importante cuando se prueba la hipótesis de diferencia de varianzas, por medio del método dado por Bartlett (Cooley y Lohnes, 1971).

Respecto al tamaño de la muestra, Gittins (1979, citado por Gould et al., 1986), sugiere que la muestra óptima es aquélla donde la razón entre el número de variables involucradas $(p)$ y el número de réplicas $(n)$, $p / n$, se encuentre dentro del intervalo de valores de $0.05<p / n<0.07$.

\section{RESULTADOS}

La tendencia histórica de los indices $\mathrm{DA}_{\mathrm{t}}$ y $\mathrm{FR}_{\mathrm{t}}$ obtenidos a partir de la ecuación 1 se muestran en las Figs. 2a y $2 b$ donde pueden observarse fluctuaciones estacionales, como ha sido señalado con anterioridad that maximize the determination coefficient of these linear functions $\left(R_{c}^{2}\right)$, called canonical correlation coefficient (Lee, 1971; Cooley and Lohnes, 1971; Morrison, 1976).

The assumptions listed previously fulfill the requirements of the $\mathrm{CC}$ method concerning random sampling and linear independence between variables and within each group, whereas the assumption of normality is only important when the hypothesis of difference of variances is proved by the Bartlett method (Cooley and Lohnes, 1971).

Regarding sample size, Gittins (1979, in Gould et al., 1986) suggests that the optimum sample is the one where the ratio of number of variables involved $(p)$ to number of replicas $(n), p / n$, is within the range $0.05<p / n<0.07$.

\section{RESULTS}

The historical trends of the indices $\mathrm{DA}_{t}$ and $F_{t}$ obtained from equation 1 are shown in Figs. $2 a$ and $2 b$ where seasonal fluctuations can be observed, as has been indicated by Solana-Sansores et al. (1989). The highest 


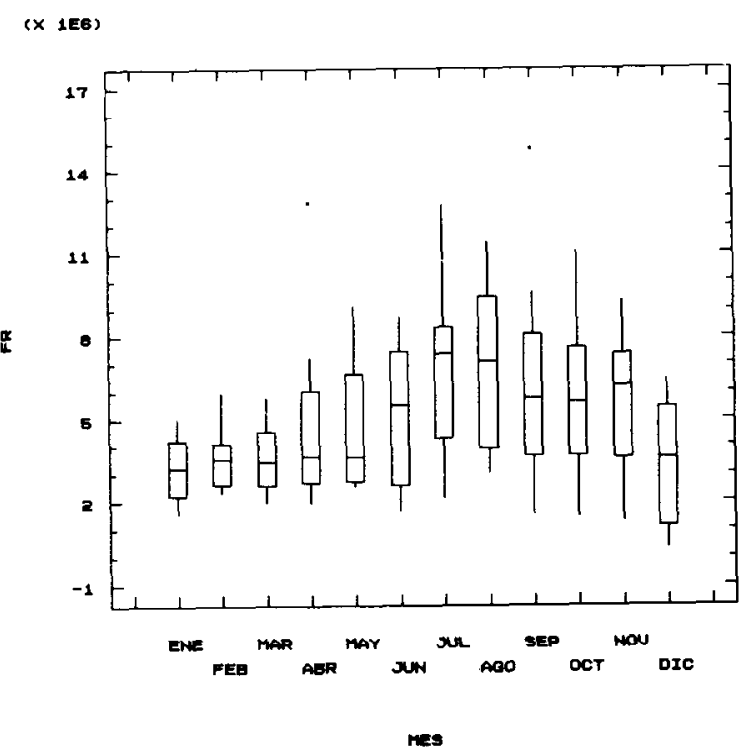

Figura 2a. Fluctuación del índice de fuerza de reclutamiento por mes. Figure 2a. Monthly fluctuation of the recruitment strength index.

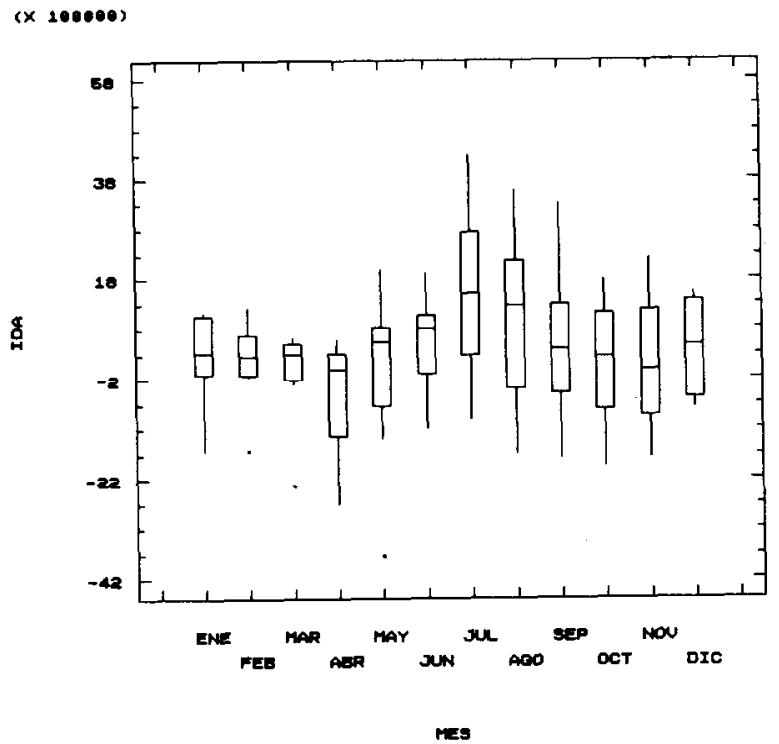

Figura 2b. Fluctuación del índice de densidad de adultos por mes. Figure 2b. Monthly fluctuation of the adult density index. 
(Solana-Sansores et al., 1989). Los valores más altos para el índice de reclutamiento $\left(F_{t}\right)$ se presentaron hacia el verano e inicio del otoño, y el índice de densidad de adultos $\left(\mathrm{DA}_{t}\right)$ siguió el mismo esquema, lo que indica la declinación del valor del logaritmo de la abundancia real de adultos. Es importante señalar que en aquellos meses donde el valor de DA fue más alto, se observó la mayor variabilidad.

Fn la etapa inicial del análisis, se obtuvo la matriz de correlación particionada entre las diferentes variables involucradas, cuyos resultados se muestran en la tabla 1 . A partir de esta información, se estimaron las combinaciones lineales de los grupos definidos de variables ambientales e indices de abundancia, para posteriormente calcular su coeficiente de correlación canónica $\left(R_{c}^{2}\right)$. Estos resultados se pueden observar en la tabla 2 , donde se muestra que la primera y segunda correlación canónica fueron altamente significativas $(p<.01)$.

En la primera combinación lineal, el esfuerzo pesquero tuvo mayor influencia, dentro del grupo de variables ambientales, mientras que en el grupo de índices poblacionales, $\mathrm{FR}_{t}$ tuvo mayor peso. Para la segunda combinación lineal los coeficientes más altos correspondieron a $\mathrm{DA}_{t}$ y a $\mathrm{PREC}_{\mathrm{t}}$. Lo anterior indica que la primera correlación mide la fuerza de la relación entre reclutas y esfuerzo pesquero, mientras la segunda determina la relación inversa entre el logaritmo de la abundancia de adultos y la precipitación pluvial.

Del análisis anterior, se obtuvo el siguiente juego de ecuaciones lineales correspondientes a la primera correlación canónica (tabla 2): values of the recruitment index $\left(F R_{t}\right)$ were found in summer and early autumn, and the adult density index $\left(\mathrm{DA}_{t}\right)$ followed the same trend, indicating a decrease in the value of the logarithm of actual adult abundance. It is important to note that greater variability was observed in those months with higher DA values.

In the initial stage of the analysis, the partitioned correlation matrix between the different variables involved was obtained (table 1). From this information, the linear combinations of the defined groups of environmental variables and abundance indices were estimated, in order to calculate the canonical correlation coefficient $\left(R_{c}^{2}\right)$. These results are presented in table 2, which shows that the first and second canonical correlations were highly significant $(p<.01)$.

In the first linear combination, fishing effort had greater influence within the group of environmental variables, whereas $F R_{t}$ had greater weight in the group of population indices. In the second linear combination, the highest coefficients corresponded to $D_{t}$ and PREC $_{t}$. This indicates that the first correlation measures the strength of the relationship between recruits and fishing effort, whereas the second determines the inverse relationship between the logarithm of adult abundance and rainfall.

From the previous analysis, the second set of linear equations corresponding to the first canonical correlation was obtained (table 2):

$$
\begin{aligned}
& X_{1}=0.313 z_{11 k}+0.917 z_{12 k} \\
& y_{2}=0.919 z_{21 k}+0.018 z_{22 k}
\end{aligned}
$$

donde $k$ es igual a $1,2, \ldots, n ; z_{i j}$ es la variable jotaésima del iésimo grupo $(\mathrm{i}=1,2) ; X_{i}$, la combinación lineal de variables ambientales; $Y_{i}$, la combinación lineal de índices poblacionales; $R_{L}^{2}=$ a 0.68 , es la correlación canónica $\left(X_{1} v s . Y_{1}\right)$.

Las correlacionesentre las nuevas variables canónicas y las originales fueron: where $k$ is $1,2, \ldots, \mathrm{n} ; z_{i j}$ the $j$ th variable of the $i$ th group $(i=1,2) ; X_{i}$ the linear combination of environmental variables; $Y_{i}$ the linear combination of population indices; $R^{2}$, the canonical correlation $\left(X_{1}\right.$ vs. $\left.Y_{1}\right)$ which is equal to 0.68 .

The correlations between the new canonical variables and the original ones were: 


$$
\begin{aligned}
& S_{1}=R_{11} c_{1}=\left[\begin{array}{ll}
1.00 & 0.14 \\
0.14 & 1.00
\end{array}\right]\left[\begin{array}{l}
0.31 \\
0.92
\end{array}\right]=\left[\begin{array}{l}
0.44 \\
0.96
\end{array}\right] \\
& S_{2}=R_{22} d_{1}=\left[\begin{array}{ll}
1.00 & 0.10 \\
0.10 & 1.00
\end{array}\right]\left[\begin{array}{l}
1.00 \\
0.02
\end{array}\right]=\left[\begin{array}{l}
1.00 \\
0.12
\end{array}\right]
\end{aligned}
$$

donde $R_{11}$ es matriz de correlación de variables ambientales; $R_{22}$, matriz de correlación de indices de abundancia; $c_{q}$, primer vector lineal asociado a variables ambientales; $d_{1}$ primer vector lineal asociado a índices de abundancia.

Estos resultados indican, por ejemplo, que 0.96 es la correlación entre el esfuerzo pesquero y la primera combinación lineal, y 1.00 es la correlación de $\mathrm{FR}_{\mathrm{t}}$, con la primera combinación lineal.

Siendo $S_{1}$ y $S_{2}$ la proporción de variabilidad del grupo de las variables ambientales $\mathrm{e}$ índices poblacionales, respectivamente, la varianza explicada por la primera variable canónica fue: where $R_{11}$ is the correlation matrix of environmental variables; $R_{22}$ the correlation matrix of abundance indices; $c_{1}$ the first linear vector associated to environmental variables; $d_{1}$ the first linear vector associated to abundance indices.

These results indicate, for example, that 0.96 is the correlation between fishing effort and the first linear combination, and 1.00 is the correlation of $F R_{t}$ with the first linear combination.

If $S_{1}$ and $S_{2}$ are the proportion of variability of the group of environmental variables and population indices, respectively, then the variance explained by the first canonical variable is:

$$
R_{1}^{2}=\frac{S_{1} S_{1}}{p_{1}}=\frac{1}{2}[0.440 .96]\left[\begin{array}{l}
0.44 \\
0.96
\end{array}\right]=\frac{1.12}{2}=0.56
$$

y, para el grupo de los índices poblacionales:

and, for the group of population indices:

$$
R_{2}^{2}=\frac{S_{2}^{\prime} S_{2}}{p_{2}}=\frac{1}{2}\left[\begin{array}{lll}
1.00 & 0.12
\end{array}\right]\left[\begin{array}{l}
1.00 \\
0.12
\end{array}\right]=\frac{1.02}{2}=0.51
$$

donde $P_{1}, P_{2}$, número de variables involucradas por grupo; $S_{i}^{\prime}$ vector transpuesto.

La redundancia de las variables ambientales, dados los índices de abundancia, $F_{t}$ y $\mathrm{DA}_{t}$, para la primera correlación canónica fue: where $P_{1}$ and $P_{2}$ are the number of variables involved per group, and $S_{i}^{\prime}$ is the transpose vector.

The redundancy of the environmental variables, given the abundance indices, $F_{t}$ and $\mathrm{DA}_{t}$, for the first canonical correlation was:

$$
R_{d x}=\frac{S_{1}^{\prime} S_{1}}{p_{1}} R_{c}^{2}=(.56)(.68)=.38
$$

Esto es, el $56 \%$ de variabilidad del grupo de las variables ambientales se explica por el
That is, $56 \%$ of the variability of the group of environmental variables is explained by the 
Solana-S. y Arreguín-S.: Cambios estacionales de abundancia del camarón café (Penaeus aztecus)

Tabla 1. Matriz de correlación entre las variables ambientales y los índices de abundancia.

Table 1. Correlation matrix between the environmental variables and the abundance indices.

\begin{tabular}{l} 
FR \\
\hline
\end{tabular}

Tabla 2. Análisis de correlación canónica entre variables ambientales (precipitación pluvial y esfuerzo pesquero) vs. los indices de abundancia de reclutas y adultos, para el periodo de 1974 a 1982.

Table 2. Canonical correlation analysis between environmental variables (rainfall and fishing effort) and the indices of abundance of recruits and adults, for the pcriod 1974 to 1982.

\begin{tabular}{lllllll}
\hline Núm. & Valor propio & $R_{c}^{2}$ & $\Lambda$ - Wilks & $X^{2}$ & gl & $\operatorname{Pr}(\mathrm{X}>\mathrm{x})$ \\
\hline 1 & 0.4668 & 0.68 & 0.50 & 64.92 & 4 & 0.0000 \\
2 & 0.704 & 0.27 & 0.93 & 6.76 & 1 & 0.0093 \\
\hline
\end{tabular}

Coeficientes canónicos para las variables ambientales

\begin{tabular}{lcc}
\hline Variable & $c_{1}$ & $c_{2}$ \\
\hline Prec. pluvial & 0.313 & 0.955 \\
Esfuerzo pesquero & 0.917 & -0.413 \\
\hline Coeficientes canónicos para los índices de abundancia & \\
\hline \multicolumn{1}{c}{ Variable } & $\mathrm{d}_{1}$ & $\mathrm{~d}_{2}$ \\
\hline Fuerza de reclutamiento & 0.999 & 0.077 \\
Densidad de adultos & 0.018 & -1.002 \\
\hline
\end{tabular}

primer factor canónico, el $68 \%$ de la misma se explica por la correlación canónica con los indices de abundancia y el $38 \%$ de la varianza se explica por el primer factor del grupo de los indices poblacionales (redundancia).

Similarmente, la redundancia en y: first canonical factor, $68 \%$ is explained by the canonical correlation with the abundance indices and $38 \%$ of the variance is explained by the first factor of the group of population indices (redundancy).

Similarly, the redundancy in $y$ :

$$
R_{d y}=\frac{S_{2} S_{2}}{p_{2}} R_{c}^{2}=(.51)(.68)=.35
$$


El $51 \%$ de la varianza de los índices es explicado por el primer factor canónico del grupo de los índices, y $R_{d y}=.35$ es la proporción de la varianza del grupo de los indices explicada por el primer factor del grupo de las variables ambientales.

Debido a que la segunda correlación canónica también fue significativa, se procedió a definir la redundancia en ella. Las ecuaciones lineales son:
That is, $51 \%$ of the variance of the indices is explained by the first canonical factor of the group of indices, and $R_{d y}=.35$ is the proportion of the variance of the group of indices explained by the first factor of the group of environmental variables.

Since the second canonical correlation was also significant, wc procceded to define the redundancy in it. The linear equations are:

$$
\begin{aligned}
& x_{2}=0.96 z_{11 k}-0.41 z_{12 k} \\
& y_{2}=0.08 z_{21 k}-0.96 z_{22 k}
\end{aligned}
$$

donde $k=1, \ldots, n, x$ e $y$ son combinaciones lincales de varianza unida, y $R_{c}^{2}=0.27$, que es la segunda correlación canónica.

La correlación entre las nuevas variables canónicas y las variables involucradas fue: where $k=1, \ldots, \mathrm{n} ; x$ and $y$ are linear combinations of united variance, and $R_{c}^{2}=0.27$, which is the second canonical correlation.

The correlation between the new canonical variables and the variables involved was:

$$
R_{d x}=(.56)(.27)=.15
$$

Para este grupo de componentes lineales, el $15 \%$ de la varianza del grupo de variables ambientales se explica por el primer factor del grupo de los índices de abundancia.

De manera similar, para el segundo grupo de variables (índices de abundancia) :
For this group of linear components, $15 \%$ of the variance of the group of environmental variables is explained by the first factor of the group of abundance indices.

Similarly, for the second group of variables (abundance indices):

$$
R_{d y}=(.51)(.27)=.14
$$

\section{DISCUSION}

Los índices definidos con anterioridad (Solana-Sansores et al., 1989) se usan para analizar su comportamiento con variables exógenas, pues permiten, primeramente, analizar el reclutamiento a partir de ellos y la evolución de la población de adultos, lo cual hace que las relaciones con otras variables sean más sencillas de observar. De otro modo, es necesario analizar por separado las abundancias estimadas para cada edad, lo que llevaría a tratar la información de manera más compleja.

En el presente estudio, se observó que las diferentes variables ambientales están estrechamente relacionadas y actúan en con-

\section{DISCUSSION}

The previously defined indices (Solana-Sansores et al., 1989) are more useful when used for exogenous variables as they enable the study of recruitment and of the evolution of the adult population, making the relationships with other variables easier to observe. Otherwise, the abundances estimated for each age would have to be studied separately and in a more complex manner.

In the present study, the different environmental variables were found to be closely related and to have an effect on the fluctuations of the different population indices. In the case of the abundance of recruits, the influence of fishing effort is clear, and the 
junto sobre las fluctuaciones de los diferentes índices poblacionales definidos. Para el caso de la abundancia de reclutas, es clara la influencia del esfuerzo pesquero, y las variaciones en la abundancia de población en general dependerán de los cambios en $F R_{t}$, aspecto que ha sido tratado por diversos autores (García, 1984). El esfuerzo pesquero, tiene una influencia directa en la estructura de la población, y la abundancia de las clases de mayor edad disminuye al aumentar este factor, como se vio en el presente análisis. Este aspecto también ha sido considerado por otros autores (Walker, 1984).

La relación que guarda la abundancia de reclutas con el esfuerzo pesquero está registrada en la primcra correlación canónica. El coeficiente del índice de fuerza de reclutamiento $\left(F R_{t}\right)$ para esta primera correlación es aproximadamente igual a 1 , lo cual significa que el coeficiente de correlación canónica $\left(R_{c}^{2}\right)$ relaciona este indice en forma lineal con los factores de variables ambientales, donde el coeficiente del esfuerzo pesquero tiene mayor peso (0.91), como se dijo en el párrafo anterior. Esta asociación se explica en términos de la estrategia de pesca, tal como lo determinaron anteriormente ArreguinSánchez et al. (1988), al efectuar un análisis de correlación cruzada, en el que encontraron un desfasamiento de un mes en los valores más altos del esfuerzo de pesca con respecto al reclutamiento. Esto es, el esfuerzo de pesca sigue los pulsos del reclutamiento, los cuales influyen directamente en los cambios de la abundancia del recurso.

Con respecto a la precipitación pluvial, aunque su coeficiente en la primera correlación canónica fue bajo, esto no significa que no tenga una influencia significativa en las fluctuaciones de los indices poblacionalesy especificamente en la abundancia de reclutas. El bajo valor del coeficiente probablemente esté asociado a que la relación no sea de tipo lineal, como lo supone la técnica de correlación canónica. Se ha dicho que esa relación es cuadrática para el camarón blanco (Penaeus setiferus) del Banco de Campeche (Gracia, 1989), y ésta es una opción por analizar para el caso del camarón café ( $P$. aztecus). También se ha afirmado que el efecto de la precipitación pluvial en la abundancia de individuos reclutas o adultos es más evidente cuando se correlaciona con capturas o abundancias de meses posteriores, (Silas et al., 1984; Walker, 1984), porque actúa como un variations in the population abundance will generally depend on changes in $F_{t}$, as reported by several authors (García, 1984). Fishing effort has a direct influence on the structure of the population, and the abundance of the higher age classes decreases as this factor increases, as was seen in this analysis. This aspect has also been considered by other authors (Walker, 1984).

The relationship between the abundance of recruits and fishing effort is recorded in the first canonical correlation. The coefficient of the recruitment strength index $\left(F R_{t}\right)$ for this first correlation is approximately equal to one, which means that there is a linear relationship between the canonical correlation coefficient $\left(R_{c}^{2}\right)$ and the factors of environmental variables, where the coefficient of fishing effort has greater weight (0.91). This association is explained in terms of fishing strategy, as determined by Arreguín-Sánchez et al. (1988) who performed cross-correlation analysis and found a shift of one month in the highest values of fishing effort relative to recruitment. That is, fishing effort follows the variations of recruitment, which directly influence the changes in abundance of the resource.

Rainfall, even though its coefficient in the first canonical correlation is low, does have a significant influence on the fluctuations of the population indices, especially on the abundance of recruits. The low value of the coefficient is probably due to the fact that the relationship is not linear, as assumed by the canonical correlation technique. Gracia (1989) reported that this relationship is caudratic for white shrimp (Penaeus setifenus) from Campeche Bank, and this is an option that should be analysed for brown shrimp ( $P$. aztecus). It has also been mentioned (Silas et al., 1984; Walker, 1984) that the effect of rainfall on the abundance of recruits or adults is more evident when it is correlated with catches or abundances of subsequent months, because it acts as an agent in the change of salinity in juvenile breeding grounds, as a carrier of nutrients, leading to a large availability of food or affecting the processes of intraspecific competition in breeding areas. Rainfall is considered to be a very important variable, that influences the migration of juveniles to fishing areas and, therefore, the magnitude of recruitment (Garcia, 1984; Gracia, 1989).

The value of explained variance, $51 \%$ for the population indices and $56 \%$ for the envi- 
agente en el cambio de salinidad en las zonas de crianza de juveniles, como acarreador de nutrientes al desencadenar una disponibilidad grande de alimento o, en el caso contrario, afectando la intensidad de procesos de competencia intraespecifica en las zonas de crianza. Así mismo, se ha informado que es una variable de suma importancia, que influye en la emigración de juveniles a zonas pesquerasy, por tanto, en la magnitud del reclutamiento (García, 1984; Gracia, 1989).

El valor de varianza explicada, de $51 \%$ para los índices poblacionales y $56 \%$ para las variables ambientales, se debe en gran medida a lo mencionado arriba: el esfuerzo pesquero tiene un efecto en la población con retraso y el reclutamiento también se ve con retraso respecto a la precipitación pluvial. A pesar de ello, el modelo obtenido permite describir la tendencia poblacional en reclutas.

Al analizar la segunda correlación canónica, se observa, aunque con menor valor de coeficiente de correlación canónica $\left(R_{c}^{2}=\right.$ $0.27 ; \mathrm{p}<0.009$ ), que el coeficiente canónico más alto para los índices poblacionales es el de los adultos con signo negativo, lo que indica que esta correlación canónica explica más significativamente la relación entre ellos y las variables ambientales, donde el coeficiente más alto fue para la precipitación pluvial. Esto concuerda con lo discutido arriba y lo mencionado por varios autores (Staples, 1985; Gracia, 1989), respecto a que con mayor precipitación pluvial aumentan los reclutas, y ello se manifiesta en la población sujeta a aprovechamiento pesquero.

Por último, de acuerdo con lo expuesto, se considera recomendable observar dicha relación a través de modelos del tipo de series de tiempo, si la información analizada es completa en el tiempo o modelos no lineales, lo cual permitiría obtener mejores índices de la relación de estos parámetros ambientales con la abundancia de camarones. Asimismo, es aconsejable realizar un análisis exploratorio del comportamiento de los indices poblacionales en un "mapa" de las variables canónicas obtenidas en este trabajo y/o de precipitación pluvial y esfuerzo pesquero.

\section{AGRADECIMIENTOS}

El presente estudio fue parcialmente apoyado por CONACYT (clave PCECBNA021228). Los autores agradecen el aporte de información a los colegas del CRIP-Tampico ronmental variables, is largely due to the delayed effect that fishing effort has on the population, and recruitment relative to rainfall. In spite of this, the model describes the population trend in recruits.

Analysis of the second canonical correlation shows that, although with a lower canonical correlation coefficient value $\left(R_{\mathrm{c}}^{2}=\right.$ 0.27 ; p $<0.009$ ), the highest canonical coefficient for the population indices is that of the adults with a negative sign, indicating that this canonical correlation explains more significantly the relationship between them and the environmental variables, where the highest coefficient was for rainfall. This concurs with that mentioned above and by several authors (Staples, 1985; Gracia, 1989), that with greater rainfall recruits increase, and this can be seen in the population subject to exploitation.

Finally, it would be advisable to determine this relation using time series models, if the information available is fully covered, or nonlinear models. In this way, better correlation indices between these environmental parameters and shrimp abundance could be obtained. Likewise, an exploratory analysis of the behaviour of the population indices on a "map" of the canonical variables obtained in this stucty and/or of rainfall and fishing effort is also recommended

\section{ACKNOWLEDGEMENTS}

This study was partially supported by CONACYT (grant PCECBNA-021228). The authors thank their colleagues from CRIPTampico of the Instituto Nacional de la Pesca and, especially, Refugio $G$. Castro-Meléndez for the data provided. Thanks are also due to Guillermo Villarreal and an anonymous referee for their valuable comments, and to Lourdes $P$. Arredondo Uribe for transcribing the manuscript.

\section{English translation by Christine Harris.}

del Instituto Nacional de la Pesca $y$, de manera muy especial, a Refugio G. Castro-Meléndez. Igualmente expresan su agradecimiento a Guillermo Villareal y un revisor anónimo, por sus sugerencias para mejorar este trabajo, así como a Lourdes $P$. Arredondo Uribe, por la transcripción del documento. 
Solana-S. y Arreguín-S.: Cambios estacionales de abundancia del camarón café (Penaeus aztecus)

\section{REFERENCIAS}

Arreguín-Sánchez, F., Solana-Sansores, R., Castro-Meléndez, R. y Medellín, $M$. (1988). Modelo de reclutamiento para la pesquería de camarón café Penaeus aztecus del noroeste del Golfo de México. CINVESTAV, IPN. Reporte técnico, México, 19 pp.

Cooley, W.W. and Lohnes, P.R. (1971). Multivariate data analysis. John Wiley, London, $364 \mathrm{pp}$.

Castro-Meléndez, R. (1982). Análisis biológico-pesquero del camarón café (Penaeus aztecus) en las costas de Tamaulipas, México. Sec. Pesca, INP, México, 87 pp.

Castro-Meléndez, R., Arreguín-Sánchez, F. y Chávez-Ortiz, E. (1986). Análisis regional del recurso camarón en aguas NO del Golfo de México (Tamaulipas y Veracruz, México). Informe de investigación, INP, México, 24 pp.

Cushing, D.H. (1984). Do discards affect the production of shrimps in the Gulf of Mexico? In: J.A: Gulland and B.J. Rothschild (eds.), Penaeid shrimps: their biology and management, $\mathrm{pp}$. 254-257.

García, S. (1984). Environmental aspects of penaeid shrimp biology and dynamics. In: J.A. Gulland and B.J. Rothschild (eds.), Penaeid shrimps: their biology and management, pp. 268-271.

Gould, R.W., Balmori, E.R. and Fryxell, G.A. (1986). Multivariate statistics applied to phytoplankton data from two Gulf Stream warm core rings. Limnol. Oceanogr., 31(5): 951-968.

Gracia G., A. (1989). Ecología y pesquería del camarón blanco Penaeus setiferus (Linnaeus, 1767) en la laguna de Términos-Sonda de Campeche. Tesis doctoral, UNAM, México, 127 pp.

Lee, P.J. (1971). Multivariate analysis for the fisheries biology. Fish. Res. Bd. Can. Tech. Rep., 244: 140 pp

Logan, D.T. (1985). Environmental variation and striped bass population dynamics: a size-dependent mortality model. Estuaries, $8(1)$ : $28-33$

Longhurst, A.R. and Pauly, D. (1987). Ecology of tropical oceans. Academic Prcss, New York.
Morrison, D.F. (1976). Multivariate statistical methods. McGraw-Hill, USA, 415 pp.

Penn, J.W. (1984). The behaviour and catchability of some commercially exploited penaeids and their relationship to stock and recruitment. In: J.A. Gulland and B.J. Rothschild (eds.), Penaeid shrimps: their biology and management, pp. 173-186.

Rothschild, B.J. and Brunnenmeister, S.L. (1984). The dynamics and management of shrimp in the northern Gulf of Mexico. In: J.A. Gulland and B.J. Rothschild (eds.), Penaeid shrimps: their biology and management, $p p$. 145-172.

Silas, E.G., George, M.J. and Jacob, T. (1984). A review of the shrimp fisheries of India: a scientific basis for the management of the resources. In: J.A. Gulland and B.J. Rothschild (eds.), Penaeid shrimps: their biology and management, pp. 83-103.

Solana-Sansores, R., Arreguín-Sánchez, F., Castro-Meléndez, R. y Medellín, $M$ (1989). Exploración de técnicas multivariadas para su uso en el estudio de la dinámica poblacional de especies sujetas a explotación pesquera: el caso del camarón café (Penacus aztécus) del noroeste del Golfo de México. Bol. Ocean. Venezuela, $28(2): 245-252$.

Staples, D.J. (1985). Modelling the recruitment processes of the banana prawn Penaeus merguiensis, in the southeastern Gulf of Carpentaria, Australia. In: Second Australian National Prawn Sem. inar, pp. 175-184.

Staples, D.J., Dall, W. and Vance, D.J. (1984). Catch predictions of the banana prawn, Penaeus merguiensis, in the south-eastern Gulf of Carpentaria. In: J.A. Gulland and B.J. Rothschild (eds.), Penaeid shrimps: their biology and management, pp. 259-267.

Unar, M. and Naamin, N. (1984). A review of the Indonesian shrimp fisheries and their management. In: J.A. Gulland and B.J. Rothschild (eds.), Penaeid shrimps: their biology and management, pp. 104-110.

Van Zelenge, N.P. (1984). The shrimp fisheries in the Gulf between Iran and the 
Arabian Peninsula. In: J.A. Gulland and B.J. Rothschild (eds.), Penaeid shrimps: their biology and management, pp. 71-82.

Villegas, L. and Dragovich, A. (1984). The Guianas-Brazil shrimp fishery; its problems and management aspects. In: J.A. Gulland and B.J. Rothschild (eds.),
Penaeid shrimps: their biology and management, pp. 60-70.

Walker, R.H. (1984). The prawn (Penaeus orientalis Kishinouye) in Pohai Sea and their fishery. In: J.A. Gulland and B.J. Rothschild (eds.), Penaeid shrimps: their biology and management, $p p$. $36-48$. 